\title{
LOKÁLIS GEOPOLITIKA ÉS TERÜLETFEJLESZTÉS
}

\section{LOCAL GEOPOLITICS, AND SPATIAL DEVELOPMENT}

\author{
Tőkés Tibor ${ }^{1}$ \\ ${ }^{1 P h D}$, adjunktus, Debreceni Egyetem, Gazdaságtudományi Kar, Világgazdasági és Nemzetközi Kapcsolatok \\ Intézet \\ tokes.tibor@econ.unideb.hu
}

\author{
Kulcsszavak: \\ lokális geopolitika, területfejlesztés, francia regionális reform \\ Keywords: \\ local geopolitics, regional development, French regional reform
}

\begin{abstract}
Összefoglalás
A lokális geopolitika nem más, mint a geopolitikai módszerek alkalmazása a helyi konfliktusok értelmezésében. E terület csak a közelmúltban került a francia geopolitikai kutatások témái közé. A területfejlesztés geopolitikájának vizsgálata a lokális geopolitika egyik fontos szakterülete Franciaországban. A területfejlesztés középszintjének kérdése eröteljesen foglalkoztatja a francia szakembereket, éppen ezért érdemes megvizsgálnunk a témát, hiszen a magyar területfejlesztés középszintjével kapcsolatos viták Magyarország esetében is folyamatosan napirenden voltak az elmúlt időszakban.
\end{abstract}

\section{Abstract}

Local geopolitics is in fact the application of geopolitical tools in the definition of local conflicts. This topic is a brand new branch of the French geopolitical research areas. In France since the 1980 's, the reforms related to the division of scope of competence between the state and territorial governments have had an increasing effect on the relationship of local communities and of those communities with the state. One of the key characteristics of this relationship is the effort to harmonize the needs of local communities and of spatial development. Researching the geopolitics of spatial development is an important issue of local geopolitics in France today. The matter of mid-level spatial development is widely challenging for French professionals therefore it is worth having a look at it - especially as this level of development has gone through major changes recently in Hungary.

\section{A lokális geopolitika, fogalma és kapcsolata a terület- és településfejlesztéssel}

A terület- és településfejlesztésnek létezik politikai dimenziója, a regionális politika, mely meghatározza az egyes országok fejlődését kötődik a politikához, az államok viselkedéséhez. Az államok viselkedését a belső és külső viszonyrendszerük egyaránt befolyásolják, ez a geopolitika kutatásának tárgykörébe tartozik [3]. A belső körülmények alakulására a regionális politika és a területfejlesztés is hatással van. Egy-egy területfejlesztési akció erőteljesen befolyásolja az ott élő emberek mindennapi életét, jövőjét és szükségleteit. Így természetes, hogy a helyi (települési, megyei és regionális) szereplők szeretnének hatással lenni e történésekre, sok esetben nem csak passzív elszenvedői akarnak lenni az eseményeknek, de aktív alakítói is. A geopolitika megközelítéséből két szempont szerint vizsgálhatjuk a regionális politikát valamint a terület- és településfejlesztést. Az egyik szempont az államok szintje. A regionális egyenlőtlenségek és az azokat megszűntetni hivatott terület és településfejlesztési tevékenységek mennyiben befolyásolják az adott államok viselkedését a többi állammal és a külvilággal kapcsolatban. Ezen egyenlőtlenségek komolyan meghatározhatják az egyes államok külpolitikai, külgazdasági stratégiáját, mozgásterét és döntéseit. İgy az államok 
szintjén a terület- és településfejlesztésnek van geopolitikai vetülete. A másik szempont a területi (helyi, megyei, regionális) szint. Mivel az ott élő emberek azok, akiknek az életére hatással vannak a különböző a terület- és településfejlesztés hatáskörébe tartozó intézkedések, ennek következtében ők azok, akik bizonyos esetekben hatnak a terület- és településfejlesztés irányaira, ezzel módosíthatják, az eredeti elképzeléseket, javíthatják, de akár mérsékelhetik is azok hatékonyságát. Ez a lokális szint természetesen összekapcsolódik az egész ország életét meghatározó nemzeti szinttel, és végső soron befolyásolja az adott ország viselkedését mind a szomszédok mind a tágabb értelemben vett regionális környezettel kapcsolatban. Ha helytálló az a megállapítás, mely szerint a terület- és településfejlesztés valóban képes befolyásolni egy állam térszerkezetének alakulását, akkor az is alátámasztást nyer, hogy ez a befolyásolás a gazdasági szerkezet és a térszerkezet alakításával hatással van az érintett állam viselkedésére is. Egy sikeres területfejlesztési politika megfelelő irányba fordíthatja egy adott ország gazdaságának fejlődését és javíthatja annak versenyképességét a nemzetközi szintéren, ez a versenyképesség-növekedés és fejlődés pedig hatással lehet vagy akár át is alakíthatja az említett állam viselkedését, viszonyát a külvilággal. Ennek köszönhetően változhat az ország geopolitikai szerepe.

Franciaországban a II. világháború utáni időszakban jelent meg a modern területfejlesztés és indult el az a folyamat, mely aztán 1982-ben a decentralizációhoz és a regionalizációhoz vezetett. Ennek az időszaknak az első felében a terület- és településfejlesztés még ellentmondást nem türő, a központi kormányzat által irányított, szakemberek segítségével felügyelt tevékenység volt. Majd, a régiók hatásköreinek kibővülésével a helyzet megváltozott. Így ma a francia területfejlesztés erôteljesen figyelembe veszi a helyi és a területi közösségek érdekeit, és lehetőséget biztosít e közösségeknek a döntésekbe való egyre nagyobb arányú beleszólásra. Ez az átalakulás egy új helyzetet eredményezett a kormányzat és a gazdasági szereplők, valamint a lakosság, a civil szereplők között: vitát generált a különböző fejlesztési kérdésekben. Ez vitát jelent a helyi közösségek illetve az egyes szereplők és a központi kormányzat érdekeivel kapcsolatban. De a párbeszéd ugyanúgy vonatkozhat konkrét lépések megtétele melletti vagy azokkal szembeni állásfoglalásokra is. Az egyeztetések az állam választott képviselői (országos, regionális és helyi), a szakemberek, a gazdasági szereplők, a civil társadalom képviselői, azaz az egyszerü állampolgárok között zajlanak. E jelenségek és kapcsolatrendszer vizsgálatára vállalkoztak francia kutatók, mely terület vizsgálatát az évek során számos tudományterület müvelői magukévá tették.

Az 1970-es években kezdődő új típusú vizsgálatok már a területfejlesztési politika és a helyi közösségek, a területfejlesztés, a földrajz és a geopolitika viszonyával is foglalkoztak. Emellett olyan kutatások is kezdődtek, melyek Franciaország „belső” geopolitikai viszonyait is feltárták. A lokális geopolitika ahogy Philippe Subra 2016-os munkájában is említi a „geopolitika leánya”, melynek kialakulására nagy hatással volt Yves Lacoste [4] és Béatrice Gibin [2] munkássága. De a geoökonómia mint a geopolitika új területe is befolyásolta a francia geopolitika fejlődését [6]. A lokális geopolitikát tehát a geopolitikához erősen kapcsolódó szakterületnek tekinthetjük, az nem más, mint a geopolitika módszereinek, eszköztárának alkalmazása a helyi konfliktusok értelmezésében, a különböző, általában államokon belüli, az esetek nagy többségében kisebb területeken folyó a hatalomért folytatott küzdelem, a helyi téttel rendelkező versengés vizsgálata, mely a helyi szereplőket alapvetően megmozgatja [9]. Ez a versengés kapcsolatos lehet a területfejlesztéssel, helyi politikai hatalommal, környezetvédelemmel, az elővárosokba történő bevándorlás kérdésével, a szegregációval, és az etnikai csoportok közötti viszonnyal, valamint számos, a helyi közösség életét befolyásoló témával.

Mint már említésre került a területfejlesztési politikának és a helyi kormányzásnak is van politikai dimenziója, Franciaországban e politikai dimenzió három faktorral magyarázható. Az első a decentralizáció kérdése, a második a területi kormányzás és a „közigazgatási levelestészta” („millefeuille administratif”, mely kifejezéssel a szakemberek Franciaország közigazgatási rendszerének rétegzettségét jellemzik) kialakulása, a harmadik pedig a területfejlesztés körüli konfliktusok megjelenése[12]. A helyzet Magyarországon is hasonló, hiszen a két ország esetében a területfejlesztésnek és a helyi kormányzásnak vannak párhuzamos tulajdonságai, ez államaink központosított közigazgatási rendszeréből és kormányzásából is következik (melyen Franciaországban már részben változtattak). Így kétségtelen tény az, hogy ebből a szempontból magyar viszonylatban is felsorolhatjuk a regionalizáció és a megyerendszer kérdését, a területfejlesztés körüli konfliktusokat és a közigazgatási reform vitáit. Még egyértelmúbb a hasonlóság, ha megemlítjük, hogy a térszerkezeti egyenlőtlenségek, a túlzott főváros-központúság és 
az ellenpólusok hiánya, valamint a központosított államszervezet, a megyerendszer fontossága számos esetben hasonló problémákat generáltak, és sokszor hasonló konfliktusokat és válaszokat váltottak ki mind a nemzeti, mind a helyi szinteken. Bizonyos szempontból - és ez a lokális geopolitika szempontja - e folyamatoknak is van geopolitikai dimenziója, hiszen itt is „hatalmak” (szereplők) vetélkedéséról van szó egy területen, egy terület feletti uralom megszerzéséért.

A lokális geopolitika segít megérteni a területi konfliktusok dinamikáját, okait és a konfliktus hiányában hasznos lehet a komolyabb problémák, a későbbi esetleges konfliktusok megelőzésében is[11] [12]. E szakterület hatalmat, rivalizálást, konfliktust, érdekeket vizsgál helyi szinten és ezen jelenségek megértésével közelebb hozhatja a problémák megoldását. A geopolitika és a földrajz viszonyát a következőképpen is leírhatjuk Yves Lacoste híres munkájából kiindulva: „ha a földrajz a háborút szolgálja" [5] akkor a geopolitika a békecsinálást vagy a háború megelőzését [10]. Ha Lacoste logikája szerint ezt a megállapítást a lokális geopolitikára alkalmazzuk, akkor a lokális geopolitika helyi szinten azt teszi, amit a geopolitika tesz a nemzetközi konfliktusokban, tárgyalásokkal és a problémák lényegére való rávilágítással segít megoldani a konfliktusokat és a különböző problémákat. Ebből következik, hogy a lokális geopolitika mérsékelheti vagy visszaszoríthatja a területi konfliktusokat és létrehozhat olyan a párbeszéd, a vita vagy a tárgyalások által generált megegyezésen alapuló döntéseket, amelyek minden területi szereplő számára elfogadhatóak lehetnek. Az előbbiek fényében meghatározható a lokális geopolitika tárgyköre. Ezek szerint a lokális geopolitika a következő területeket vizsgálja: A területfejlesztési tervek körüli konfliktusok; a részvételi demokrácia, a párbeszéd és a nyilvános viták; területi igazgatás, a területi rendszer és a kormányzás; a választási geopolitika [12]. Míg a területfejlesztés geopolitikájának vannak a hagyományos geopolitikába illeszthető vonatkozásai, addig a lokális geopolitika területfejlesztési kérdésekben is az államok szintjén, azokon belül vizsgálódik. A lokális geopolitikai konfliktust az érdekek és a nem állami szeplők nagy száma jellemzi A szereplők tekintetében, lokális geopolitikai szereplő lehet minden olyan természetes és jogi személy, aki felléphet adott terület keretei között vagy adott területi konfliktusban. A konfliktus az, amely létrehozza a szereplőket szereplőként, tehát szereplőnek így az tekinthető, aki hat vagy van rá képessége, hogy hasson az adott konfliktusra. Az állam a lokális geopolitikai konfliktusok sajátos szereplője, mivel szerepe nem egyértelmű, illetve lehet szereplő, tét és szintér is egyben. Ebből kifolyólag a lokális geopolitikai konfliktusokban az állam is szerepet játszik, de nem szükségszerüen jelentőset, perifériára szorulhat a konfliktusban, lehet egyszerre keret, döntőbíró és szereplő is [10].

\section{A lokális geopolitika szereplői}

A szereplők - ahogy a hagyományos geopolitikai konfliktusok szereplői is - eltérő érdekekkel, eltérő megközelítésekkel rendelkeznek egy terület uralásának kérdésében, de magával a területtel kapcsolatban is. Különbség van a szereplők száma és megjelenésük, illetve a beavatkozásuk intenzitása között. Emellett a geopolitikai konfliktusban léteznek olyan szereplők egy területen, melyek a konfliktus kezdetén még nem tekinthetők szereplőknek, csak a konfliktus folyamata teszi őket azzá. E különbségek akkor mutathatók ki igazán, ha figyelembe vesszük a hagyományos geopolitikai konfliktusokat és összevetjük őket a lokális geopolitikai konfliktusokkal. Egy terület feletti uralom szempontjából a lokális geopolitikai konfliktusok szereplői akkor is uralhatják párhuzamosan az adott teret, ha eltérő megközelítéssel rendelkeznek a terület használatának kérdésében, illetve ha érdekeik a terület feletti uralom teljesen más dimenzióira vonatkoznak. Míg a hagyományos geopolitikai konfliktusban egy terület uralása szempontjából általában csak egy szereplő jöhet számításba - mely riválisait végül legyőzi, - ellenkező esetben uralma nem lesz stabil. A szereplők a lokális geopolitikai konfliktusban bonyolult rendszert alkotnak. Ennek elemzése lényeges kérdés: Melyek a rendszer alkotói, akik a szembenálló feleket alkotják? Az oldalak száma nem minden esetben egyezik meg a szereplők számával. E szereplők ismerete és pontos meghatározásuk a konfliktus lezajlása szempontjából fontos. Milyen a kapcsolat közöttük? Ezen kapcsolatok milyen viszonyban vannak a konfliktus tétjével? A rendszeren belül milyenek az erőviszonyok? Előbbi két kérdés azért fontos, mert előrejelzést adhat a szereplők viselkedéséről, illetve a konfliktus végkimeneteléról. A konfliktus és a versengés majdhogynem szinonimák. A versengés inkább egy általánosan fenntartható helyzet két vagy több szereplő között, az érdekek konfliktusa, amely kapcsolataik hátterét adja. A konfliktus általában konkrét összeütközést jelent, a 
konfliktus a versenyhelyzet kikristályosodása adott területen két vagy több szereplő között pontosan meghatározott célok érdekében [10].

\section{A területi kormányzás mint a lokális geopolitika vizsgálati területe}

A lokális geopolitika egyik kutatási területe a területi kormányzás, igazgatás, és a rendszer változásainak megismerése, e változások okainak és következményeinek a feltárása. Elemzi azt a gyakorlatot és azokat a kapcsolatokat, amelyek azon szeplők között léteznek, akik lehetővé teszik a különböző területeken (területi egységeken) belül a hatalomért folyó versengést. A kormányzás fontos kérdés a szereplők szempontjából, tehát nem mindegy, hogy milyen elvek szerint múködik. Éppen ezért az egyes területi szereplók igyekeznek beleszólni a területi kormányzás kérdésibe. Ennek tipikus példája a francia decentralizáció és a közigazgatási reform, mely 1982-óta folyamatosan szakmai, politikai és közéleti viták tárgyát képezi, és a francia lokális geopolitika egy különleges kutatási területét alkotja.

\section{A regionális reformok lokális geopolitikai vizsgálata - Franciaország}

A 2016-os regionális reform alapvetően átrajzolta Franciaország regionális térképét, mellyel nem mindenki értett egyet. E reform a Balladur-reformok utódjának is tekinthető, ám annak csak egy részét valósította meg. A Sarkozy-kormányzat időszakában Edouard Balladur közigazgatási reformtervezete, a francia regionális rendszer átalakítását is előrevetítette, melyben a francia régiók számát 22-ről 15-re csökkentették volna, ám a tervezet Nicolas Sarkozy és a jobboldal 2012-es választási vereségével lekerült a napirendről [14]. A 2016-os reform elődjeivel ellentétben sokkal több konkrétumot tartalmazott, ám néhány szakértő szerint kevéssé megalapozott kutatások képezték intézkedéseinek kiindulópontját. Hibájának tekintik, hogy nem vette figyelembe, illetve nem alkalmazta a megyeáthelyezés lehetőségét, pedig azt több megyei közösség is elvárta volna. Ragaszkodtak a régióhatárok sérthetetlenségéhez, és nem új régiókat hoztak létre, csak összevonták a már meglévő 22 régiót. Ez ugyanaz az eljárás volt, mint amivel az 1950-es években létrehozták a tervezési régiókat [8]. Ezek esetében a megyehatárokat tekintették sérthetetlennek [7]. Magyarországon az 1990-es években hasonló volt a helyzet, mivel hazánkban a közigazgatás területi reformját szintén a megyehatárok érintetlenül hagyásával tudták csak elképzelni. Azóta már világossá vált, hogy az akkor létrehozott régiók megrekedtek az előkészítés fázisában, majd elpusztult az, ami nem is létezett, és 2010-tôl Magyarország visszatért a hagyományos megyei beosztáshoz. Franciaországban a helyzet éppen ellenkező irányba tart, hiszen a régiók fúziójával kisebb számú és nagyobb területü régiókat hoztak létre. A fúzió ellen bizonyos esetekben a szakma és a helyi választott képviselők is fölemelték hangjukat; ez a jelenlegi regionális térképen is meglátszik [12]. Bizonyos érintetlenül hagyott régiók éppen ezért maradhattak meg jelenlegi területükön. Vannak olyan régiók, amelyek estében figyelembe vették a helyi identitást, a helyi érdekeket, viszont más régiók esetében nem. Szakmai szempontból a területfejlesztés középszintjével kapcsolatban létrehozták a metropolisz térségeket (amivel a szakma egy része is egyetértett), amelyek a fóvárost ellensúlyozatják és a nagyrégiók segítségével talán lesz erre reális lehetőségük. Ám kétségtelen tény, hogy a metropoliszok új regionális szereplóként jelennek meg a regionális tervezésben és bizonyos szempontból - a mi a források megszerzését illeti - a régiók versenytársaivá válhatnak. Így a metropoliszok a települések mellett „régi-új” szereplőként lépnek be a területi rendszerbe [15]. A pólusvárosok, illetve a metropolisz térségek 2016 előtt is jelen voltak a rendszerben [18] ám jelentőségüket csak a NOTRe törvény (Loi Nouvelle organisation territoriale de la République - mely más törvényekkel együtt tulajdonképpen Franciaország új területi beosztását és területi közigazgatási rendszerének reformját jelentette) erősítette meg [20].

A másik jelentős a helyi szereplők ellenállását is kiváltó kérdés a megyék megszüntetésének kérdése. A megyerendszer az idők folyamán összeforrt a Francia Forradalom eszméjével és mélyen a francia néplélek tudatában gyökerezik. A megye hívei elképzelhetetlennek tartják azt a tervezetet, amit a kormányzat támogatni látszott - később aztán el is állt ettől az elképzelésétől - hogy a megyéket teljesen megszüntessék [12]. A konfliktus a regionális reform kérdésében a helyi közösség szintjén a megyepárti és a regionalista megközelítés között volt, illetve eltérő elképzeléseket fogalmaztak meg az egyes pártok képviselői is. A helyi konfliktus szereplői még a megyei, illetve regionális szervezetek, gazdasági szereplők, civil szervezetek és a szakma képviselői voltak. E 
szereplők egy része elkötelezett ugyan a reform mellett, de nem tarja szükségszerűnek a megyék megszüntetését. A szakma egy része ebből a szempontból a régiósítás mellett van, de abban nem értenek egyet, hogy a francia régiók milyenek legyenek (terület, lakosság gazdasági teljesítőképesség/hagyományok közigazgatási határok központok, pólusvárosok kérdése). A gazdasági szereplők és a civil szervezetek is megosztottak a kérdésben. A megyepártiak egyszer már indítottak egy „el a kezekkel a megyémtől” mozgalmat. Ez is oka volt a kormányzat visszalépésének a megyerendszer megszüntetésének tervétől. Ám a kérdést végül a politika (a kormányzat reformelképzelései) döntötte el így a III. Decentralizációs Reform következtében a régiók számát az európai ország területen 13-ra csökkentették. A reform természetesen Franciaország tengerentúli területeit is érintette ezek az úgynevezett tengerentúli megyék (DOM) és területek (TOM) [16].

\section{1. táblázat: A Francia régiók 2016-os reform elött és után./ The regions of France before and after the reform of 2016}

\begin{tabular}{|c|c|c|}
\hline $\begin{array}{l}\text { A } 2016 \text { előtti } 22 \text { régiós } \\
\text { fölosztás }\end{array}$ & A 2016 január 1-tôl érvényes 13 régiós fölosztás & Régiószékhely \\
\hline Alsace & \multirow{3}{*}{ Grand Est (Alsace-Champagne-Ardenne-Loirraine) } & \multirow{3}{*}{ Strasbourg } \\
\hline Champagne-Ardenne & & \\
\hline Loirraine & & \\
\hline Aquitaine & \multirow{3}{*}{$\begin{array}{l}\text { Nouvelle-Aquitaine (Aquitaine-Limousin-Poitou- } \\
\text { Charentes) }\end{array}$} & \multirow{3}{*}{ Bordeaux } \\
\hline Limousin & & \\
\hline Poitou-Charentes & & \\
\hline Auvergne & \multirow{2}{*}{ Auvergne-Rhône-Alpes } & \multirow{2}{*}{ Lyon } \\
\hline Rhône-Alpes & & \\
\hline Bourgogne & \multirow{2}{*}{ Bourgogne-Franche-Comté } & \multirow{2}{*}{ Dijon } \\
\hline Franche-Comté & & \\
\hline Languedoc-Roussillon & \multirow{2}{*}{ Occitanie (Languedoc-Roussillon-Midi-Pyrénées) } & \multirow{2}{*}{ Toulouse } \\
\hline Midi-Pyrénées & & \\
\hline Nord-Pas-de-Calais & \multirow{2}{*}{ Hauts-de-France (Nord-Pas-de-Calais-Picardie) } & \multirow{2}{*}{ Lille } \\
\hline Picardie & & \\
\hline Haute-Normandie & \multirow{2}{*}{ Normandie } & \multirow{2}{*}{ Rouen } \\
\hline Basse-Normandie & & \\
\hline Île-de France & Île-de France & Paris \\
\hline Centre-Val de Loire & Centre-Val de Loire & Orleans \\
\hline Pays de la Loire & Pays de la Loire & Nantes \\
\hline Bretagne & Bretagne & Rennes \\
\hline $\begin{array}{l}\text { Provence-Alpes-Cote } \\
\text { d'Azur }\end{array}$ & Provence-Alpes-Côte d'Azur & Marseille \\
\hline Corse & Corse & Ajaccio \\
\hline
\end{tabular}

Forrás: saját szerkesztés a 2015-29 tv. és a régiók elnevezéseiről szóló rendeletek alapján [17]

A 2014-es III. Decentralizációs Reformcsomag keretein belül megvalósították már a Sarkozy kormányzat ideje alatt is napirenden lévő regionális reformot, a régiók számának csökkentését. A tervezet első verziója szerint a régiókat érintő közigazgatási reform következtében a régiók számát az európai ország területen összevonásokkal 22-ről 14-re csökkentették volna. Viták sorozata után 2014 július 23-án a Francia Nemzetgyúlés azonban a 13 régiós fölosztást fogadta el. A viták természetesen a régiók számáról, illetve az összevonásokkal voltak kapcsolatosak. E vitákban, a választott képviselőik által, megjelent az egyes területi közösségek véleménye is. A rendszert kritizáló 
politikusok és szakértők arra hivatkoztak, hogy csak a baloldali politikusok véleményét vették figyelembe a reform során. A reformpártiak természetesen elutasították ezt a feltételezést, és amellett álltak ki, hogy ez a lehető legmegfelelőbb fölosztás adott feltételek és Franciaország akkori lehetôségei között. Az akkori kormányzat szerint kompromisszumkészségüket az is megmutatta, hogy eredetileg egy 14 régiós tervezetet szerettek volna elfogadni, ám ezt végül második olvasatra egy 13 régiós tervezetté alakították (1. táblázat).

A reform során több régiót összeolvasztottak. A francia régiók megfelelnek az Európai Unió által használt NUTS II-es, azaz a tervezési-statisztikai régiók követelményeinek is. A régiók új hivatalos elnevezései 2016 október 1-tôl a következők:

- Grand Est: Alsace, Champagne-Ardenne és Loirrain,

- Nouvelle-Aquitaine: Aquitaine, Limousin és Poitou-Charentes,

- Auvergne-Rhône-Alpes: Auvergne és Rhône-Alpes,

- Bourgogne-Franche-Comté: Bourgogne és Franche-Comté,

- Région Occitanie: Languedoc-Roussillon és Midi-Pyrénées,

- Hauts-de-France: Nord-Pas-de-Calais és Picardie,

- Normandie:Haute és Basse-Normandie.

A többi régió az Île-de-France, Bretagne, Pays de la Loire, Centre Val de Loire, Provence-AlpesCôte d’Azur és Korzika változatlan maradt (1. ábra).

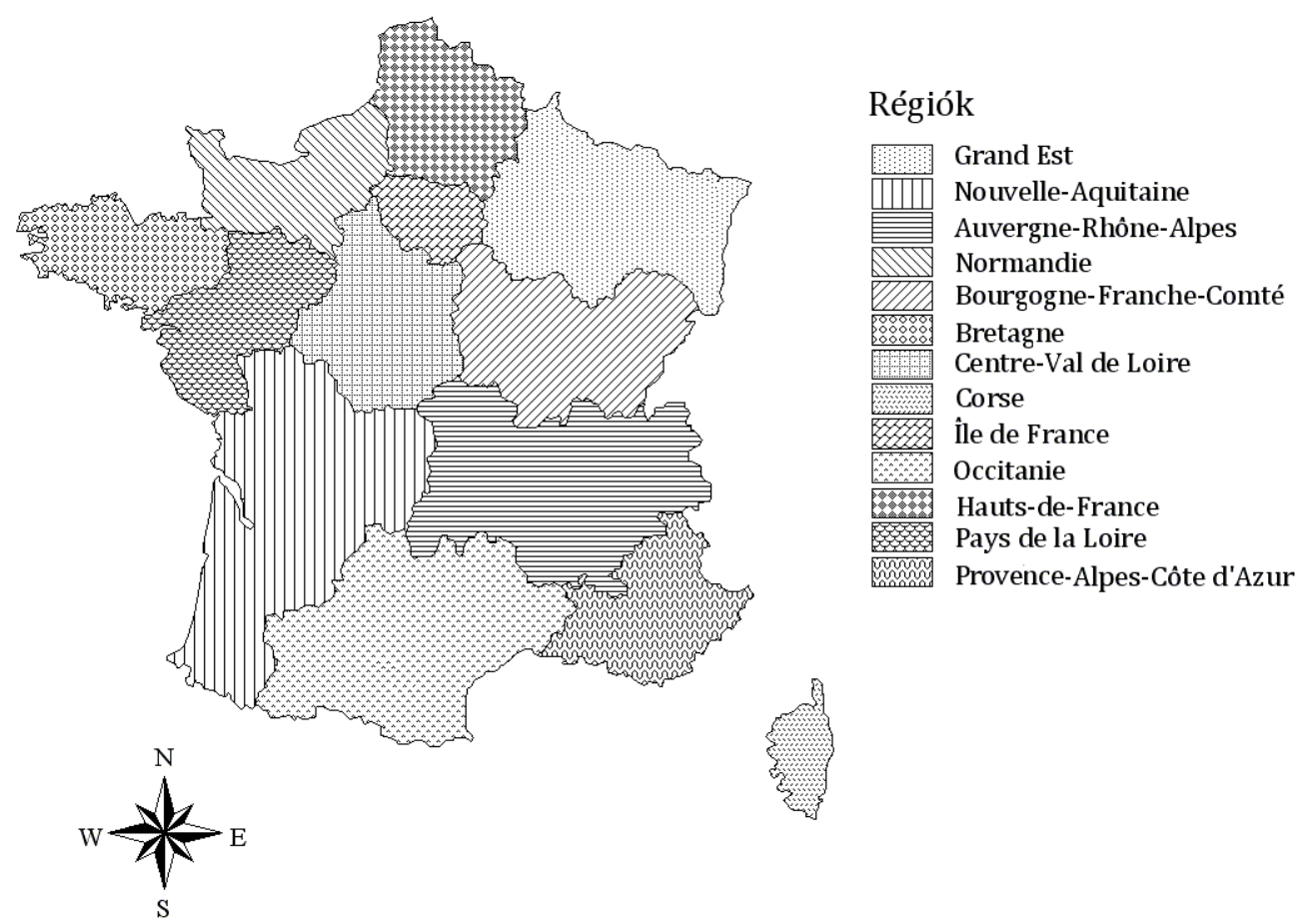

1. ábra: A 2016-ban kialakított regionális beosztás Franciaországban, / The regions of France after the reform of 2016.

Forrás: saját szerkesztés www.legifrance.gouv.fr. és www.cget.gouv.fr. alapján [24] [25]

Néhány új régió példája azt mutatja, hogy a régiók összevonásaival kapcsolatban vannak ellentmondások, ezeket érdemes megemlíteni. Több régió esetében figyelembe vették a történelmi hagyományokat az összevonásoknál, így például azt a régi igényt, miszerint a két Normandiát össze kell vonni, teljesítette a reform, emellett Bretagne és Korzika esetében is tiszteletben tartották a történelmi hagyományokat. Korzika esetében megerősítették a különleges igazgatású területi közösség státust. Ugyanakkor Elzász esetében nem vették figyelembe e hagyományokat, sőt másik két régióval vonták össze. Viszont a régió székhelyéül Strasbourgot jelölték meg, ám ez a 
régiószékhely excentrikus helyzete miatt hátrányosan is érintheti a kialakított régió mindennapi életét. Igaz az, hogy jelentősége miatt (népesség, EU) mindenképpen ezt a várost kellett regionális székhelynek választani, illetve e választás kézenfekvőnek tűnt.

A reform mellett számos érvet sorakoztattak föl annak támogatói a szocialista kormányzat, azon régiók közvéleményének egy része, melyekkel kapcsolatban az összevonások az elképzeléseiknek megfelelően alakultak, a metropoliszok, és a szakmai szervezetek. Érvük az volt, hogy a nagyobb régióméret hatékonyabbá teszi a területi tervezést és a regionális fejlesztést, ugyanakkor olcsóbbá, hatékonyabbá és átláthatóbbá teszi a közigazgatást. Érvelésük szerint a régióhatárok megállapítása a lehető legmegfelelőbb mind szakmailag, mind politikailag, ezeket a történelmi és társadalmi-gazdasági szempontok figyelembevételével jelölték ki. Az ideális, az európai átlaghoz közelítő régióméret nagyobb teljesítményü és dinamikusabb régiókat eredményez. Tehát a reform átgondolt tudatos tervezés eredménye, amely már évtizedek óta esedékes volt. A reform ellenzői: a megyerendszer mellett állók, vagy az azzal kevésbé elégedett szereplők (közöttük vannak összevonás pártiak is, akik nem a reform ellenségei, csak annak formájával nem értenek egyet), az ellenzék, a szakértők egy része, az egyesített régiók lakosságának azon része, akik szerint az összevonások nem megfelelően alakultak. Szerintük a reform nem hatékony, mivel a települési társulásokat a régiók mellé emeli a területfejlesztésben, melyek majd versenyeznek a fejlesztési forrásokért és ez fölösleges duplázódást és szükségtelen versenyhelyzetet jelent. A reform nem biztosít olcsóbb közigazgatást, nem szüntet meg adminisztratív szinteket, nem egyszerüsíti a rendszert, nő a lakosság költsége és csökken az elérhetőség a régióméret megnövekedésének következtében. Az ellenzők szerint az új régióhatárok meghúzása politikai alkuk eredménye és nem áll mögötte megfelelő szakmai tanulmány és kutatás, sem valódi regionális akarat. A reform során összekeverték a teljesítményt és a dinamizmust a lakosságszámmal és a régiómérettel. A reform szükséges, de a szocialista kormány belpolitikai okokból szánta rá magát, ezért nem megfelelően átgondolt, emellett nem megoldás a problémákra és nem fogja kellőképpen növelni az ország és régiói versenyképességét [12].

A reform kétségtelen eredménye az, hogy megerősítette a régiót, mint a területfejlesztés eszközét. Rendet teremtett a hatáskörök között, ez jelentős előrelépés. A Balladur-reform több elemét megvalósította (régiók számának 22-ről kb. 12-re csökkentése, 11 Metropolisz, Nagy-Párizs, kompetenciák tisztázása). Olyan összevonásokat is tartalmaz, amelyek évtizedek óta esedékesek: Pl.: Alsó és Felső-Normandia, Nord-Pas-de-Calais-Pikárdia. Kétségtelen tény, hogy valóban voltak olyan összevonások, melyek nem kellően indokoltak. Több régió esetében a térszerkezeti megfontolások inkább megyeáthelyezést indokoltak volna, így ezen összevonásokat megyeáthelyezéssel hatékonyabban megoldhatták volna. Ennélfogva a reform hibájának tekinthető, hogy nem nyúl a régióhatárokhoz, megyéket nem helyez át. A kritikusok érve, miszerint a Balladur-reform kimunkáltabb volt, csak bizonyos szempontból állja meg a helyét. Valóban igaz az, hogy a tervezet hosszabb, alaposabb kétpárti egyeztetés eredménye volt, és szakemberek, valamint jelenlegi és egykori helyi és országos politikusok bevonásával igen széles volt azoknak a köre, akiket bevontak a munkába. Ennek ellenére hibája az volt, hogy a reformmal kapcsolatosan konkrét intézkedéseket és menetrendet nem tartalmazott.

\section{A regionális reformok lokális geopolitikai vizsgálata - Magyarország}

Magyarország esetében az ország jelenlegi regionális rendszerének kialakítását az 1990-es években kezdték meg. A rendszert az Európai Unió elvárásainak megfelelően alakították ki. Az 1998as Országos területfejlesztési Koncepcióban [21] hét tervezési-statisztikai régióról volt szó ezek:

- Észak-Magyarországi Régió: Borsod-Abaúj-Zemplén Megye, Heves Megye, Nógrád Megye

- Észak- Alföldi Régió: Hajdú-Bihar Megye, Szabolcs-Szatmár-Bereg Megye, JászNagykun-Szolnok Megye

- Dél-Alföldi Régió: Békés Megye, Csongrád Megye, Bács-Kiskun Megye

- Nyugat-Dunántúli Régió: Győr-Moson-Sopron Megye, Vas Megye, Zala Megye,

- Közép-Dunántúli Régió: Fejér Megye, Veszprém Megye, Komárom-Esztergom Megye

- Dél-Dunántúli Régió: Baranya Megye, Tolna Megye, Somogy Megye

- Közép-Magyarországi Régió: Pest Megye 
A fenti régiók lettek az Magyarország hivatalos NUTS II régiói. A regionális székhelyek tekintetében azonban akkor nem tudtak megegyezni erről csak az 1999 évi XCII törvény rendelkezett, mely módosította a területfejlesztési törvényt. Ily módon a törvény után a Regionális Fejlesztési Tanácsok és a hozzájuk kapcsolódó Regionális Fejlesztési Ügynökségek a következő városokban székeltek Észak-Magyarországi Régió Miskolc, Észak- Alföldi Régió Debrecen, Dél-Alföldi Régió Szeged, Nyugat-Dunántúli Régió Győr, Közép-Dunántúli Régió Székesfehérvár, Dél-Dunántúli Régió Pécs, Közép-Magyarországi Régió Budapest. Ezen nagyvárosok tekinthetők az adott régiók székhelyeinek.

2012-ben a II. Orbán Kormány, visszatér a hagyományos és Magyarországon nagy hagyománnyal és jelentős hatáskörökkel rendelkező erős megyékhez. A régiót, mint területi közösséggé továbbfejleszthető közigazgatási egységet eltörölték. A regionális területfejlesztési tanács utóda a regionális területfejlesztési konzultációs fórum ugyan regionális döntésekben hivatott dönteni, ám mivel sem állandó munkaszervezettel, sem törvényileg meghatározott pontos területi lehatárolással nem bír, nem tekinthető másnak, mint a statisztikailag egy csoportba sorolt megyék időszakos gyülésének.

A magyarországi régiók jelenleg csak tervezési statisztikai kategóriák, nem tekinthetők területi közösségeknek, de még térkategóriáknak sem. A II. Orbán Kormány ezzel pontot tett a regionális intézményrendszer kialakulásának az 1990-es években megakadt folyamatának végére azzal, hogy az addig csak elvben a statisztikai és tervezési szempontból létező kvázi-regionális rendszert megszüntette, és helyette a megye kezébe tette a területfejlesztés regionális folyamatainak ellenőrzéséhez szükséges pénzügyi forrásokat és döntési jogosultságot.

\section{6. Összegzés}

A területfejlesztés kétségkívül a nagyobb területi egységek felé halad, Magyarországon ez visszájára fordult. Franciaországban a régió jól teljesít, mert van választott képviselőtestülete és saját anyagi forrásai, valamint a leghatékonyabb területfejlesztési eszköz, a tervszerződések alapja. A tervszerződések a hatékony gazdasági tervezés, a terület- és településfejlesztés megvalósulásának érdekében jöttek létre, tulajdonképpen egy partnerségi viszonyt intézményesítenek az állam és a régiók között. A régióknak az állammal kötendő tervszerződéseit a regionális tanács hagyja jóvá és szavazza meg annak feladatait, vállalásait, költségvetési forrásait. A szerződések öt évre szólnak és csak a regionális tanács döntése után emelkednek jogerőre [1]. A régiók kialakításával és a tervszerződések bevezetésével csökkentették a regionális különbségeket Franciaországban [13]. Jelenleg Magyarországon ennek egyik feltétele sincs meg. A régió hatékonyabbá és olcsóbbá teszi mind a közigazgatást, - mivel olcsóbb kisebb hivatali apparátusa van - mind a tervezést, mivel nagyobb területre hatékonyabban lehet tervezni, jobban el lehet osztani a forrásokat. Bizonyíték erre, hogy Franciaországban mérséklődtek a regionális különbségek [23] és ez részben a hatékony regionális rendszernek köszönhető. Ha megfigyeljük a régió franciaországi fejlődését látható, hogy a regionális rendszer kiépülése ott is lassan haladt, sőt a fejlődés sokszor meg is torpant. A jelenlegi regionális rendszer és a régiók jelenlegi határai többször is módosultak és jelenleg úgy látszik, hogy a közeljövőben ismét módosulni fognak. A francia példa azt mutatja, hogy még annak ellenére is nehéz átállni egy alapvetően megyerendszerre épült közigazgatási és területfejlesztési rendszerről egy regionális rendszerre, ha arra megvan a politikai és társadalmi akarat és a gazdasági szükségszerűség is indokolja. A magyar régió bukását az okozta, hogy e tényezők egyike sem volt meg, és így semmi sem tette lehetővé egy regionális rendszer kialakítását. Franciaországban jelenleg a régió az elsődleges területfejlesztési térkategória, a regionális szint fontossága kimagasló a francia közigazgatásban, a regionális politikában és a területfejlesztésben. Magyarországon ezzel ellentétben a megye a közigazgatás és a területfejlesztés területi szintjének legfontosabb egysége, és ez a közeljövőben nem is fog megváltozni. Nem lehet egyértelműen kijelenteni, hogy a magyar közigazgatás szervezés tévúton jár, a „visszamegyésítés” koncepciójával, ám azt is figyelembe kell venni, hogy a Magyarországihoz hasonló francia szisztéma területfejlesztési szempontból mindig akkor veszített hatékonyságából, amikor a regionális szervek hatásköreit gyengítette és erőforrásait elaprózta. 


\section{Felhasznált és hivatkozott irodalom:}

[1] Desjardins; X. DE Lamarliere, I.G. 2016: L'aménagement du territoire en France. . La documentation Française. Paris. 183 p.

[2] Gibin, B. 2005: Nouvelle géopolitique des régions françaises. Fayard. Paris. p.976

[3] Gauchon, P (SZERK), Delannoy, S-Huissoud, J-M. 2011: Dictionnaire de géopolitique et de géoéconomie. PUF. Paris. p.659.

[4] LACOSTE, Y. 2012: Géopolitique-la longue histoire d'aujourd'hui. Larousse. Paris. p.336

[5] LAcoste, Y. 2012 : La géographie, ça sert, d’abord, à faire la guerre-La Découverte. Paris (Az 1976-os kiadás 2012-es kiegészített kiadása) p.53

[6] LOROT, P 1999: La nouvelle grammaire des rivalités internationales in: Lorot, P.(szerk) : Introduction de la Géoéconomie. Economica. Paris. pp.11-30

[7] Merlin, P. - ChOAY F. 2015: Dictionnaire de l'urbanisme et de l'aménagement. La documentation Française. Paris. 839 p.

[8] MERLin, P. 2007: L'aménagement du territoire en France. La documentation Française. Paris. 174 p.

[9] Subra, P. 2008: L’aménagement, une question géopolitique! Hérodote 2008/3 ( $\left.{ }^{\circ}{ }^{130}\right)$, p.222-250

[10] Subra, P. 2012 : La géopolitique, une ou plurielle? Place, enjeux et outils d'une géopolitique locale, Hérodote 2012/3 $\left(\mathrm{n}^{\circ}\right.$ 146-147), p.45-70

[11] Subra, P. 2014: Géopolitique de l'aménagement du territoire, Armand Colin, Paris, p. 351

[12] Subra, P. 2016 : Géopolitique local. Armand Colin. Paris. p.335

[13] Thoumelou, M. 2016: Collectivité territoriales. Quel avenir? La documentation Française. Paris. p.284

[14] ToKes T. 2015: A francia és magyar területfejlesztés hasonlóságai és különbségei. Studia Geographica 30. A Debreceni Egyetem Földrajzi Tanszékeinek Kiadványa, Debreceni Egyetemi Kiadó ISSN 0209-4835 ISBN 978-963318-565-0 p.224

[15] Tókés T. 2015: Similarities and Differences in Hungarian and French Counterpole Programmes. Studii Europene nr. 6. ECSA-Moldova Chisinau. ISSN 2345-1041. pp.165-180

[16] Tőkés T. 2016: A CGET és a regionális reform Franciaországban. In: Pajtókné, Tari I; Tóth, A (szerk.) Magyar Földrajzi Napok 2016 : konferenciakötet : VIII. Magyar Földrajzi Konferencia, Eger, MFT, Agria Geográfia Alapítvány, Eszterházy Károly Egyetem, pp. 621-630.

[17] A régiók elnevezéseiról szóló rendeletek:

Décret $\mathrm{n}^{\mathrm{0}}$ 2016-1262 du 28 septembre 2016 portant fixation du nom de la région Grand Est.

Décret $\mathrm{n}^{\circ}$ 2016-1263 du 28 septembre 2016 portant fixation du nom et du chef-lieu de la région Normandie. Décret $\mathrm{n}^{\circ}$ 2016-1264 du 28 septembre 2016 portant fixation du nom et du chef-lieu de la région Occitanie.

Décret $n^{\circ}$ 2016-1265 du 28 septembre 2016 portant fixation du nom et du chef-lieu de la région Hauts-de-France. Décret n ${ }^{\circ}$ 2016-1266 du 28 septembre 2016 portant fixation du nom et du chef-lieu de la région Auvergne-RhôneAlpes.

Décret no 2016-1267 du 28 septembre 2016 portant fixation du nom et du chef-lieu de la région Nouvelle-Aquitaine. Décret $\mathrm{n}^{\circ}$ 2016-1268 du 28 septembre 2016 portant fixation du nom et du chef-lieu de la région BourgogneFranche-Comté

[18] Loi $\mathrm{n}^{\circ}$ 2014-58 du 27 janvier 2014 de modernisation de l'action publique territoriale et d'affirmation des métropoles (MAPTAM)

[19] Loi $\mathrm{n}^{\mathrm{o}}$ 2015-29 du 16 janvier 2015 relative à la délimitation des régions, aux élections régionales et départementales et modifiant le calendrier électoral

[20] Loi n 2015-991 du 7 août 2015 portant nouvelle organisation territoriale de la République (NOTRe)

[21] 35/1998 (III.20) OGYH

[22] 1999 évi XCII törvény

[23] Chiffre-Clés 2020 des regions. https://regions-france.org/chiffres-cles-des-regions/

[24] www.cget.gouv.fr-2016.10.29

[25] www.legifrance.gouv.fr 